\title{
SUPPLY CHAIN ANALYSIS ON PRODUCT RETURNS FROM ONLINE PURCHASE TRANSACTIONS: CUSTOMER'S EXPERIENCES
}

\author{
RAM DESHMUKH $^{1}$, D. RAMESH BABU ${ }^{2 *}, K_{\text {V. NARASIMHA RAO }}^{3} \&$ D. RAGHAVAKUMARI ${ }^{4}$ \\ ${ }^{1}$ Professor and Head of Department, Department of EEE, S R Engineering College, Warangal, Telangana, India \\ ${ }^{2}$ *Assistant Professor, Department of Mechanical Engineering, S R Engineering college, Warangal, Telangana and Research \\ Scholar, Department of Mechanical Engineering, Koneru Lakshmaiah Education Foundation, Vaddeswaram, \\ Guntur, Andhra Pradesh, India \\ ${ }^{3}$ Professor, Department of Mechanical Engineering, Koneru Lakshmaiah Education foundation, Vaddeswaram, \\ Guntur, Andhra Pradesh, India \\ ${ }^{4}$ Assistant Professor, Department of ECE, Sumathi Reddy Institute of Technology for Women, Warangal, Telangana, India
}

\begin{tabular}{|l|}
\hline ABSTRACT \\
The present study was carried out to analyzethe product returns and associated costs to the customer, when the products \\
are purchased online and returned to the supplier. Supply chain management links the manufacturers to the customers \\
through intermediaries. Some of online purchase transactions made by customers and needed to return the products due \\
to non-acceptability by customers for several reasons are studied. Customer responses are collected through a survey \\
from 114 respondents in respect of return of goods, reasons of product return and costs associated with the return. \\
Satisfaction level of customers against reputed online E-Commerce companies' viz., Amazon, Flipcart, Club factory, \\
Snapdeal are collected and analyzed. From the results it is found that Majority of popular online E-commerce \\
companies are not troubling customers through return charges. Only $7.1 \%$ respondents paid return charges. Majority of \\
people found satisfied on the issue of return charges. \\
KEYWORDS: Supply Chain Returns, Online Shopping, E-Commerce, Cost of Returns \& Customer Satisfaction
\end{tabular}

Received: Jun 09, 2020; Accepted: Jun 29, 2020; Published: Jul 23, 2020; Paper Id.: IJMPERDJUN2020429

\section{INTRODUCTION}

Supply chain management innovations created more opportunities for easy reach of products to the customers. Ecommerce companies became important stake holders in the online business. E-Commerce companies are popular now in India and worldwide due to the ease of operation, easy booking, numerous options/models to choose, convenience in payment, delivery convenience etc. However, at times the products need to be returned in case of non-satisfaction.

Supply chain returns are a challenge to the suppliers due to associated costs of purchase, transaction and logistics. Suppliers and manufacturers have got this risk of return of product form unsatisfied customer due to varied reasons. Some of the reasons are

- Wrong product delivered

- Specifications are different to that of ordered

- Visual quality parameters like color, design, size or features different to theappearance in the online portal 
(this may be customers perception)

- Incorrect address

- Damaged product during transportation

- Malfunctioning of the product

- Defects

- $\quad$ Fitting problem (in case of garments, shoes, clothing items, etc.,)

Some of these reasons could be from customer perception and can be with no reason. Online business companies should be ready to accept the returns from the customers if they want to compete and sustain in the online market. However, suitable protection be ensured in the terms and conditions of the sale/contract with regard to return/refund policy. Some of the strategies companies use could be

- Applying some nominal fee as return charges

- Imposing certain $\%$ of fee based on the cost of the product

- No return charges at all

\section{LITERATURE OVERVIEW}

$\mathrm{Xu}$ (2009) reported about consumer returns policies with respect to manufacturer/supplier terms and conditions, contract clauses, consumer's decision factors with regard to genuine returns/false returns etc., They proposed a model to devise a rate for buy-back for returned and new items. They suggested that manufacturer must receive returned product directly from consumer instead of receiving through retailer. Alternatively, the retailers may be given a sales rebate for the returned goods[1].

Ferguson et al (2006) studied about false returns which doesn't have any cosmetic or functional defect.The costs associated include the repackaging, refurbishing(in case necessary) and processing and testing[2].

Ding and Chen (2008) studied the construction of flexible return policy with respect to three level supply chains exclusively for products of short life-cycle. They also reported the coordination requirement for flexible return policy[3].

Molenkopf et al(2007)developed a theory on returns management with respect to supply chain strategy. They have also investigated the process of returns management connecting marketing/logistics relationship[4].

Ram Deshmukh et al (2020) and Ramesh Babu et al (2019) studied the work related to food products.[6,7,8]

Zhe Pei et al (2014) focused on the depth of return policies, i.e. full return or partial return and also the fairness of the return policies. The author used structural equation model for the study and concluded that ease of return and fairness improved the customer confidence in the e-trailer. [10]

Tran. T et al (2018) presented the profits based on quota based return policies and emphasis that resellers gains a lot with this. The study shows the profit variation with centralized and decentralized models and recommends the manufacturer to aid the reseller with overstock protection. [11] 
While many researchers have studied in the direction of return policies, Hannu et al. concentrated on the customer behaviors and reason to return an online bought product in fashion. The result of these study categories the returning behaviors are identified and are linked to the time of return. [12]

The impact of return strategies and leadership strategies on market share of the company, price and profits incurred for retailers in a duopoly market in studied in Jing Chen [13]. The study shows that money back guarantee has positive impact on the leadership strategy and return product expenses can be counterbalance by salvage value.

To find the situation where the money back guarantee is effective is studied by Yi et al. [14]. The author found that selling the product with money back guarantee (MGB) will increase the profit and important for mid-quality retailers and adding compensation to MGB will significantly improve for low-quality retailer sales.

Wang.Y [15] investigated the relationship of lenience, quality and fairness of return policy with the repurchase of the customer for the same e-tailer using structural equation modeling. Leniency played a most influential factor for customer repurchases intension. The quality of return policy must be effective to retain customers and hence the author recommends improving the same.

Several other researchers reported about project management, agri and food related entrepreneurship and business [16-22].

The present study was conducted to investigate the customers experiences on product returns for the transactions of purchases made through online ecommerce websites.

\section{MATERIALS AND METHODS}

A structured questionnaire was prepared using google form with selective questions and probable responses. Option was given to the respondents to choose multiple answers where ever necessary. A total of 114 customer's data was collected and analyzed. Data analysis is carried out using Microsoft excel. It may be mentioned here that some cases, the respondents have marked multiple options for answers of some questions, as the reasons are multiple for their cases.

\section{RESULTS AND DISCUSSIONS}

From the structured questionnaire, the data is analyzed using Microsoft excel and presented as bar charts and pie charts.

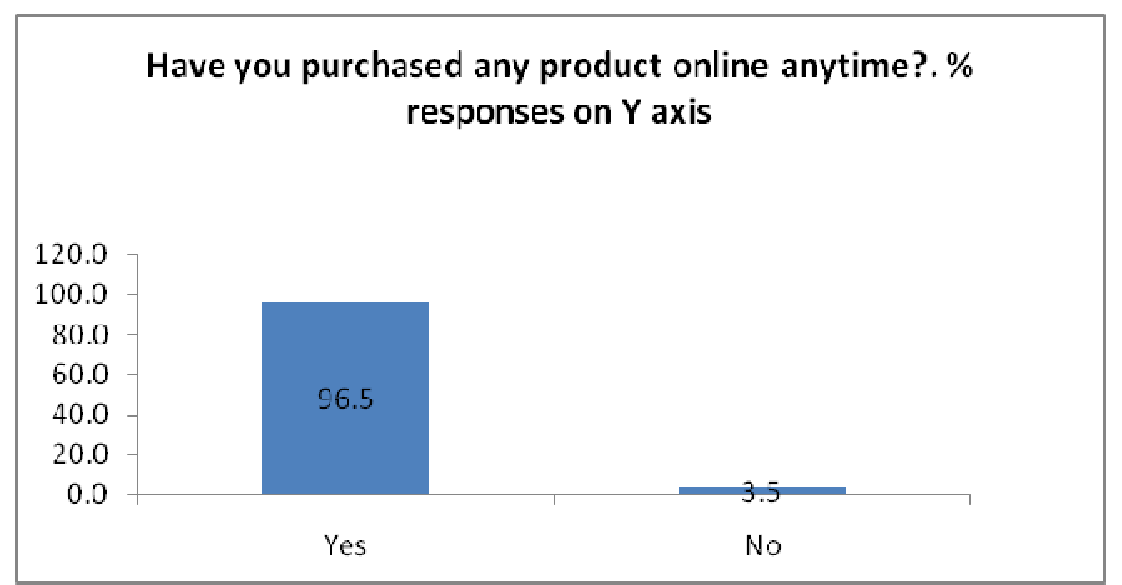

Figure 1: Question on whether the respondent purchased any product online any time.

From figure 1, we can see that $96.5 \%$ of the survey respondents have purchased product atleast once online. The 
basic question ensured that the remaining questions related to online purchases, returns, refunds and return policy conditions are dealt with appropriately.

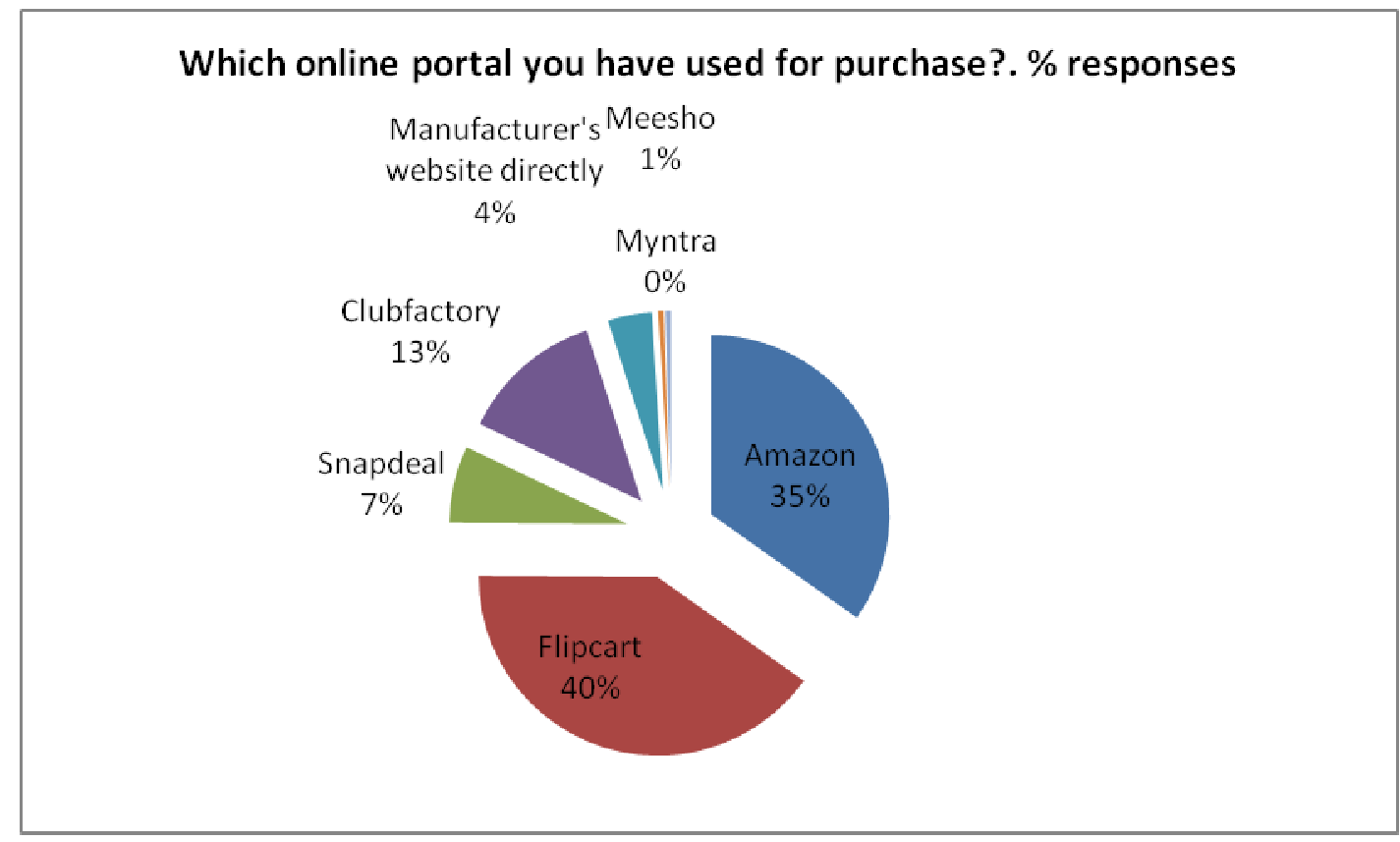

Figure 2: Details of online portals used for purchase by the respondents

Most of the respondents appeared to be purchased from Flipcart, Amazon with 40 and $35 \%$ respectively. Clubfactory has been used by $13 \%$ respondents and Snapdeal with $7 \%$ apart from $4 \%$ of manufacturer's website directly. This data shows that the popular websites are Flipcart and Amazon relatively.

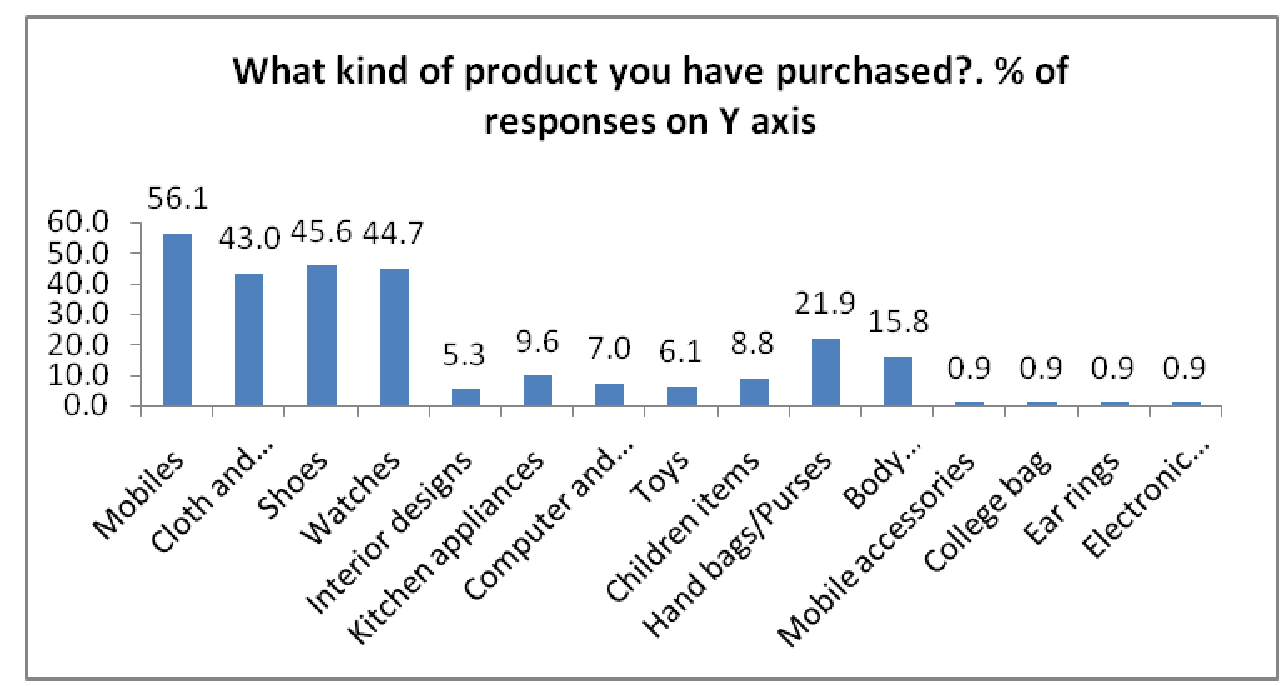

Figure 3: Details of different products purchased by the respondents of this survey

Majority of respondents, i.e., $51 \%$ bought mobile phones from online purchase, may be due to competitive and better discounted prices compared to the direct shopping. Other products are cloth, Shoes, watches, Hand bags with \% of respondents bought are 43, 45.6, 44.7, and 21.9 respectively. These can be treated as major list of types and kinds of products purchased by the respondents. Other miscellaneous products whose $\%$ is less than 20 include interior designs, kitchen appliances computers, children items, body sprays, mobile accessories, college bags, ear rings, electronic items, etc., 


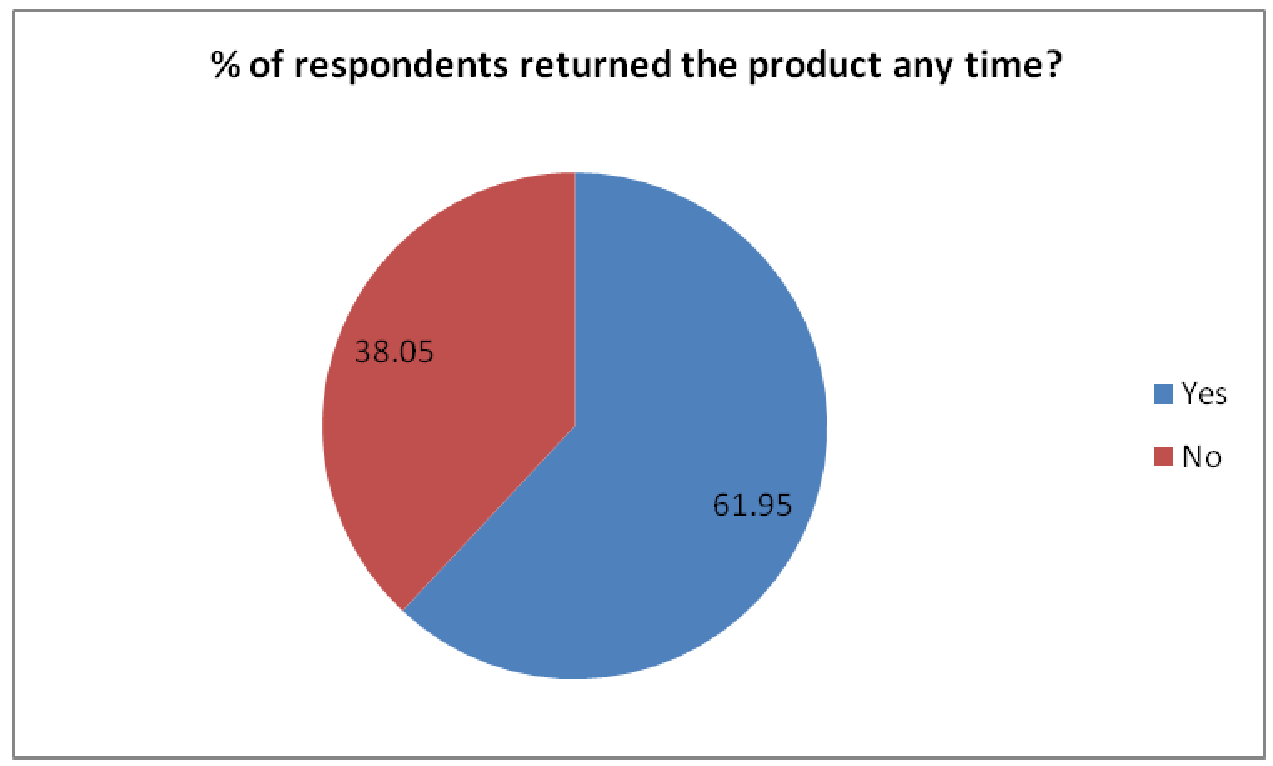

Figure 4:Details of how many respondents returned the product any time

It can be seen from figure 4 that $61.95 \%$ of respondents returned their product atleast once. These members are important for the present study to further identify the return policy issues and charges associated with returns.

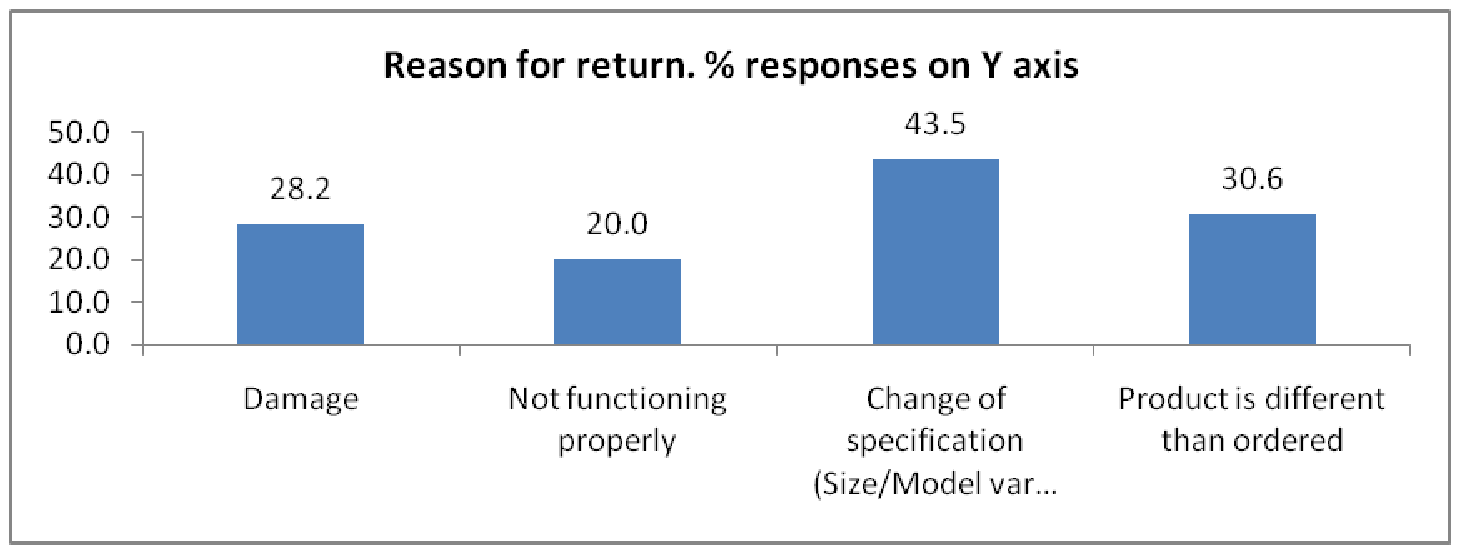

Figure 5: Details of reasons for return

From figure 5, it can be interpreted that major cause of return is change of specification ( size/model/variety). $43.5 \%$ respondents returned their product due to this reason. The other important reasons are damage, not functioning properly; product is different than ordered with \% of respondents of 28.2, 20.0, 30.6 respectively. This shows that respondents returned only on genuine reasons to return. 


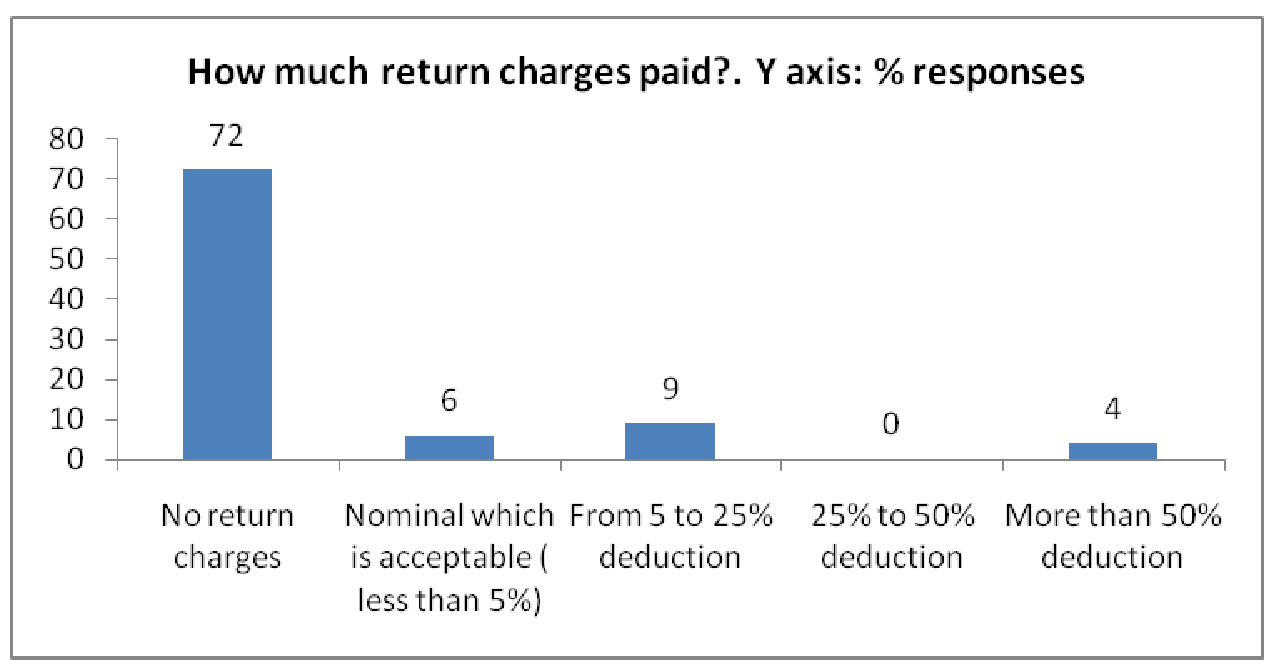

Figure 6: Details of how much returns charges paid by the respondents

From figure 6, we can see that majority of online companies did not charge any return charges, due to which customers look happy by their answer for the last question of this survey, i.e, whether respondents are discouraged to buy online due to return charges. Majority of respondent's found not discouraged due to this factor. Thisis an encouraging parameter for further growth of online business, especially the return policies of major online players like Flipcart, Amazon. Only 9\% of respondents indicated that they have paid back the return charges @ range between 5 to 25\%.6\% respondents claimed that they paid less than $5 \%$ return charges.

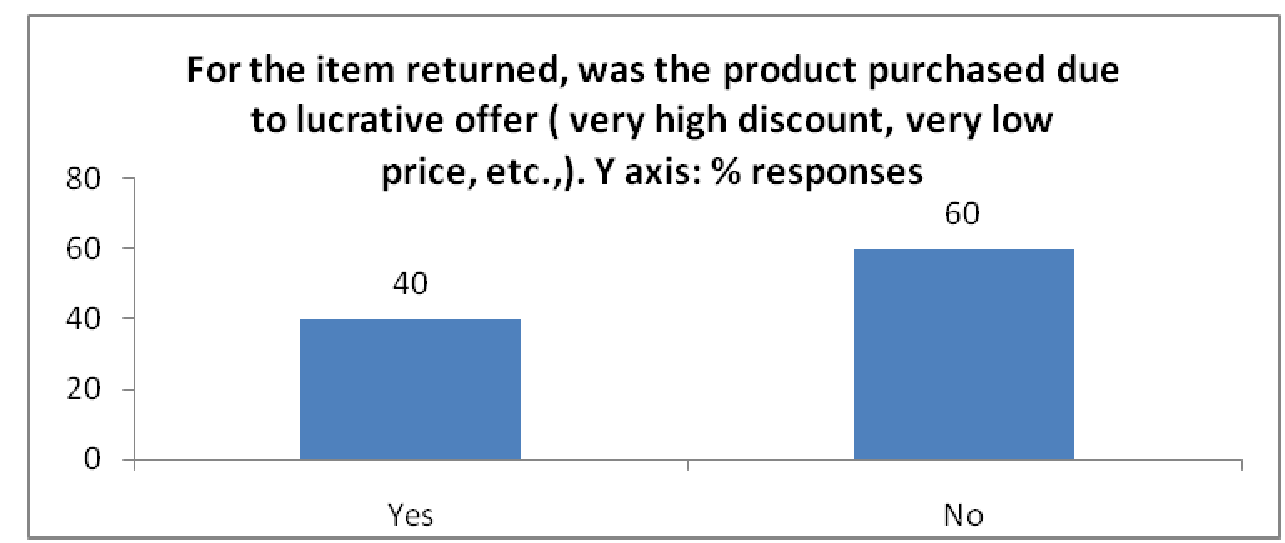

Figure 7: Details of respondents about the item returned, whether that product was purchased due to lucrative offer.

Interesting responses are found with respect to the enquiry to know, whether the product needed to be returned, was originally bought due to lucrative offer which includes very high discount, very low price,etc.,. $60 \%$ of the respondents replied with "no" which a good and healthy sign of customer's temptation of very low price, not taken by suppliers as a weak point to push low quality goods. This is a healthy sign from manufacturer's point of view towards customer. About $40 \%$ respondents mentioned that "yes". This can be interpreted with dubious offers by less popular or low quality standard companies selling online. One needs to be very cautious about these kinds of lucrative offers leading to returning of goods (figure 7). 


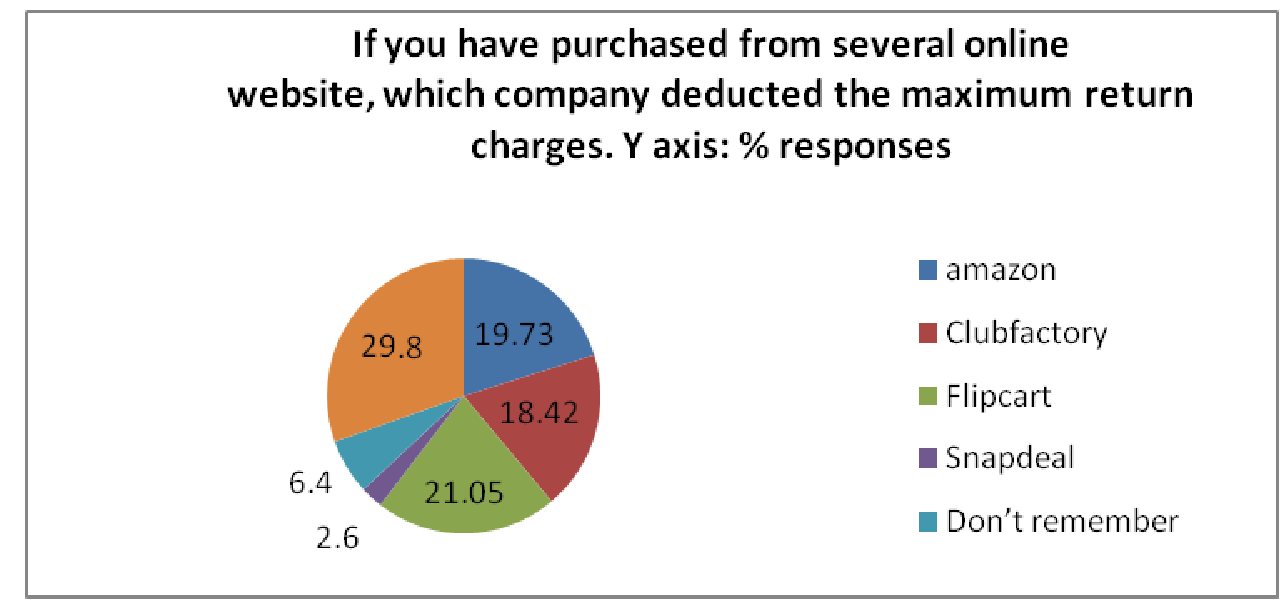

Figure 8: Details of maximum return charging online companies, from respondents view point.

From figure 8 it is clear that all reputed or major companies like Amazon, Club factory, Flip cart appeared to be the cause of worry for the respondents whose experience is not good due to high return charges. The return policies of the reputed companies are always displayed on their website with conditions and terms for return policy are clearly mentioned including \% of charges in case of return. This aspect needs proper attention of customers before buying and should draw attention of online vendors to modify their clauses of terms and condition with respect to return policy.

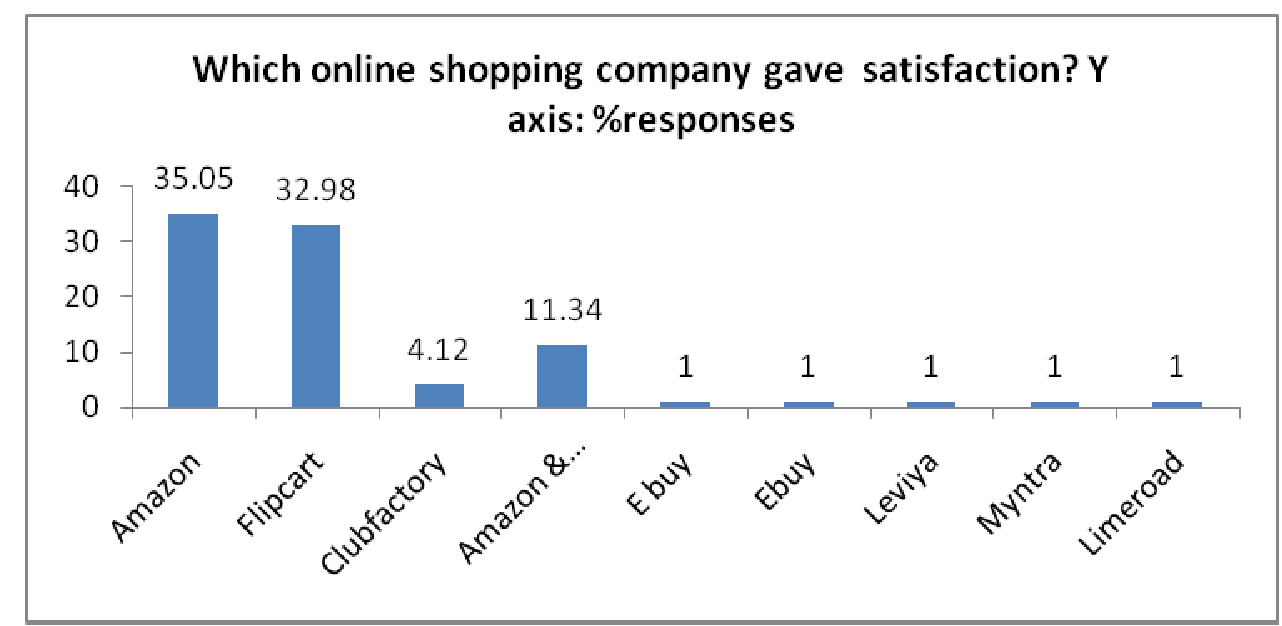

Figure 9: Details of relative comparison of which online shopping company gave satisfaction to the respondents.

From figure 9, we can clearly see that Amazon, Flipcart got highest acceptance from respondents with 35 and $32.9 \%$ respectively. $4 \%$ respondents satisfied with Clubfactory. It is interesting that $11.3 \%$ of respondents found to be satisfied cumulatively for Amazon and Flipcart. All remaining companies found to obtain less satisfaction compared to the reputed companies. 


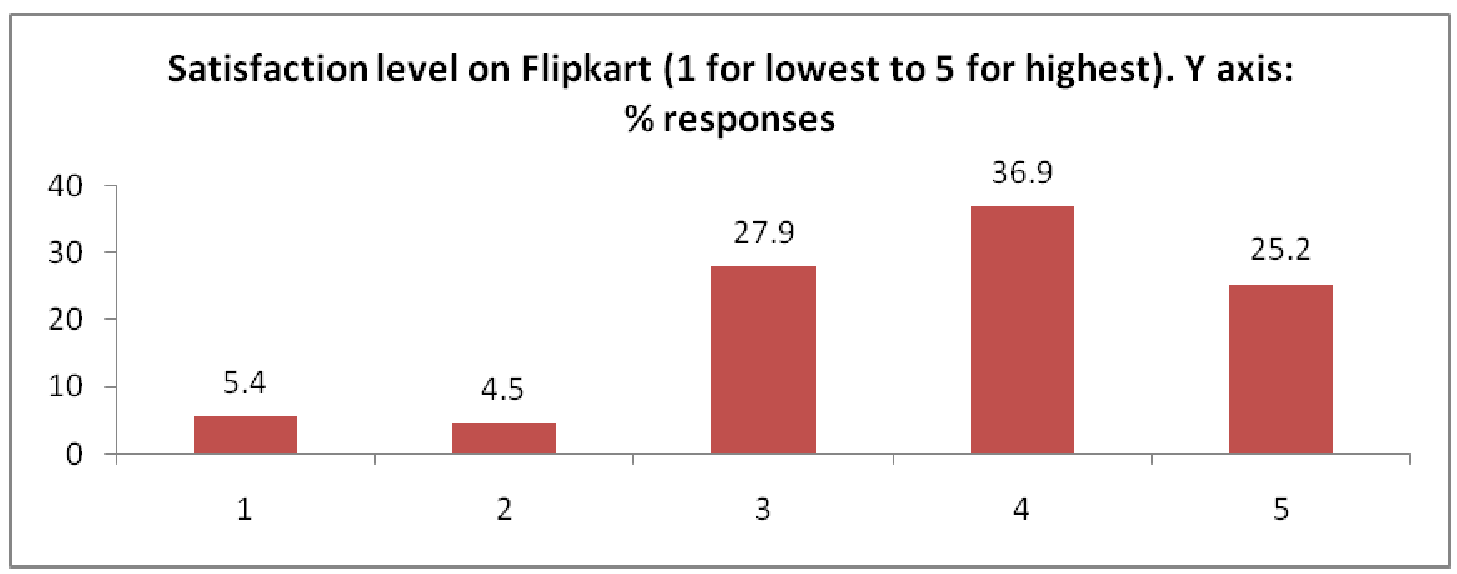

Figure 10: Details of satisfaction level on Flipkart from respondents

From figure 10, we can see that about $3 \%$ of respondents gave a rating of 4 and $25 \%$ respondents gave a rating of 5 , which indicates highest satisfaction. Almost $62 \%$ respondents gave feedback of 4 and above on a scale of 1 for lowest and 5 for highest level of satisfaction. This is a good sign for online shopping business of flipkart. However $5.4 \%$ respondents gave a score of 1 as satisfaction level.

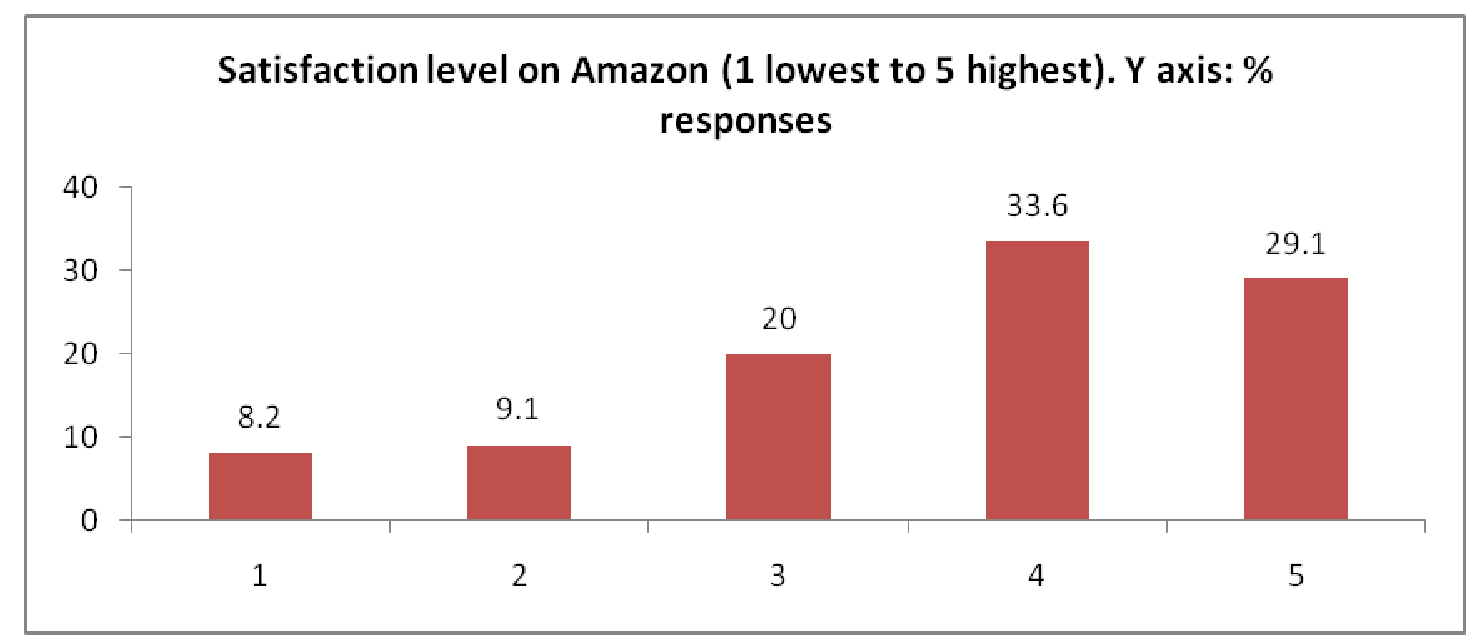

Figure 11: Details of Satisfaction level of customers on Amazon

Respondent's scoring on satisfaction level on Amazon is given in figure11, which gives positive opinion on Amazon with $62.7 \%$ respondents giving a feedback of above 4 satisfaction on a scale of 1-5 ( 1 for lowest and 5 for highest satisfaction level). 33.6\% respondents gave a satisfaction level score of 4 and $29.1 \%$ respondents gave a score of 5 . However few respondents $(8.2 \%)$ found to give 1 as satisfaction level. In another study, Amazon was found to be better accepted by customers than Flipcart (Chaudhary and Kumar 2016). That study was comparison of only Amazon and Flipcart [5]. 


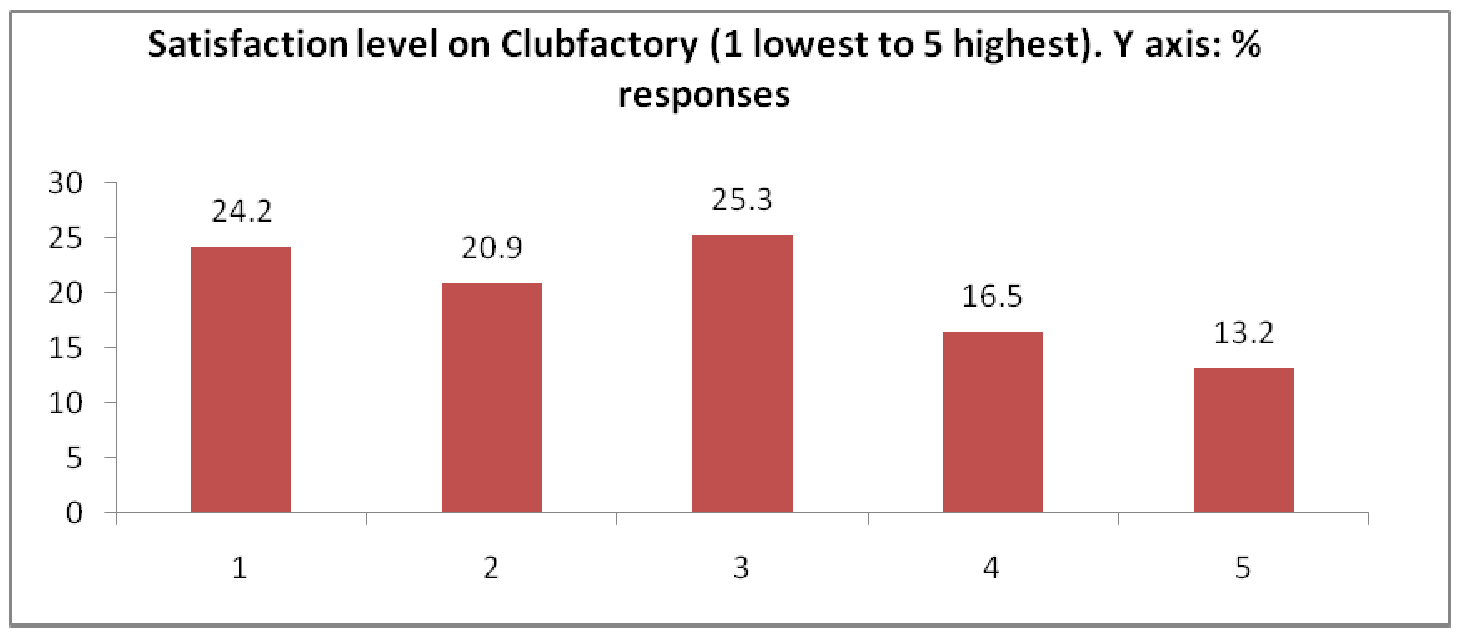

Figure 12: Details on satisfaction level on Clubfactory

From figure12, it can be seen that Clubfactory has got less score on satisfaction level from the customer's point of view. Almost $70 \%$ respondents gave a score of less than 3 on 1 to 5 scale (1 for lowest and 5 for highest satisfaction level). This indicates poor acceptance of Clubfactory by the respondents. Above 4 and 5 scores are given by $16.5 \%$ and $13.2 \%$ respectively.

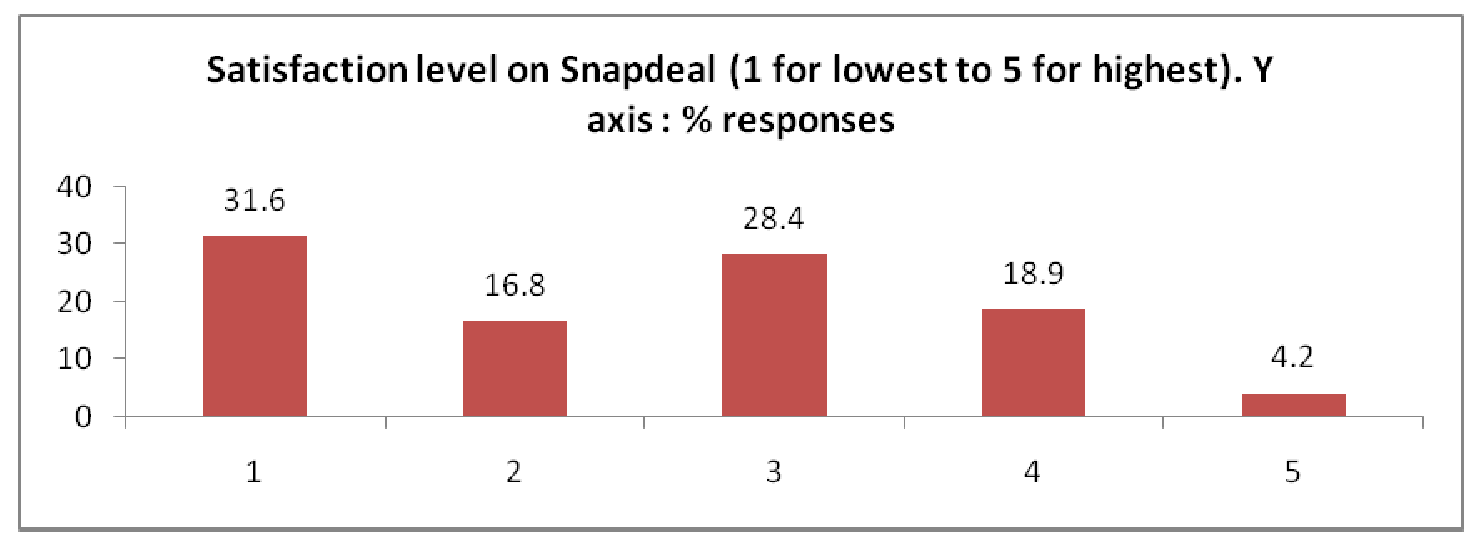

Figure 13: Satisfaction level of respondents about Snapdeal products

It is found from figure13 that acceptance by respondents is poor with regard to Snap deal online shopping company. The score of 5 is given by only $4.2 \%$ of respondents. Only $18.9 \%$ people gave a score of 4 and almost $76 \%$ of respondents gave below 3 satisfaction level (on a scale of 1-5) 


\section{Are you discouraged due to one or two bad experiences of returns? ( Are you going to stop buying online due to bad experiences), \% responses}

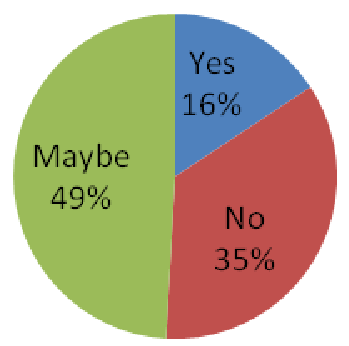

Figure 14: Details of responses on whether respondents are going to stop buying online due to bad experiences?

From figure 14 , it can be concluded that only $16 \%$ felt to be discouraged due to poor return policies, bad experiences online due to various reasons. About 49\% respondents opined that they "may be" stopping buying online due to bad experience of online buying. 35\% people mentioned that "No', which is a good sign for the reputed and standard online traders whose return policies are clear on terms and conditions and no hidden charges post- purchase on product returns. This gives boost to the online shopping business to tap the potential of online sales.

\section{CONCLUSIONS}

Supply chain returns are affected by several reasons. This study reveals the details of products, charges associated with returns, return policies, satisfaction levels for several major online business portals like Amazon, Flipcart, Clubfactory and Snapdeal. Majority of respondents of this study are online shoppers and their experiences on product returns were discussed in detail. It is found that approximately $62 \%$ of respondents gave a rating score of above 4 on a scale of 1 to 5 (1 for lowest satisfaction level and 5 for highest satisfaction level) for Amazon and Flipcart compared to Clubfactory and Snapdeal or any other online portal they dealt with. It is also found that mobiles are the major item bought by the respondents from online shopping. Most of the respondents did not pay any return charges when they returned the product. Interesting to note that only few people had bad experience regarding return policy. From the results it is found that majority of popular online E-commerce companies are not troubling customers through return charges. Only $7.1 \%$ out of 94 respondents who returned the products found to be paying return charges (specifically in the range of 5 to $25 \%$ of product cost). $73.4 \%$ people responded that no return charges levied by the supplier. This indicates that reputed online companies' return policies are well accepted by people

\section{REFERENCES}

1. Su, X. Consumer Returns Policies and Supply Chain Performance. Manufacturing \& Service Operations Management,(2009), 11 (4), 595-612. http://dx.doi.org/10.1287/msom.1080.0240.

2. Ferguson, M., Guide Jr, V. D. R., \& Souza, G. C. Supply chain coordination for false failure returns. Manufacturing \& Service Operations Management,(2006), 8(4), 376-393.

3. Ding, D., \& Chen, J. Coordinating a three level supply chain with flexible return policies. Omega, (2008),36(5), 865-876.

4. Mollenkopf, D., Russo, I., \& Frankel, R. The returns management process in supply chain strategy. International Journal of 
Physical Distribution \& Logistics Management, (2007).

5. Chaudhury K, Kumar S. Customer Satisfaction Towards Flipkart and Amazon : A Comparative Study. IJAR\&D, Vol. 2, No. 1, January-June, 2016, pp. 35-42

6. Ram Deshmukh, D Ramesh Babu and K V Narasimha Rao., "Pressure Testing Results (As A Decision Tool For Deciding Low Oxygen Or Ultra-Low Oxygen Or High Oxygen Storage) Of Semi- Hermetically Sealed Controlled Atmosphere Storage Insulated Chambers". IJMPERD, (2020), vol 10, No.1, pp. 531-540. DOI:10.24247/ijmperdfeb202045

7. Beliya, Ayush, et al. "Satisfaction of consumers by using online food services." International Journal of Humanities and Social Sciences 8.4 (2019): 35-44.

8. D Ramesh Babu, Ram Deshmukh, K V Narasimha Rao, M RajyaLaxmi, Kafila and T Sabita, "Awareness on Calcium Carbide Ripened Fruits and Recommendations for Toxic Free Artificial Ripening of Fruits”, International Journal of Engineering and Advanced Technology, (2019), vol.9, no.2.pp.2779-2782.

9. Ramesh Babu, D., Narasimha Rao, K. V. and SyamKolati., "The Design of Refrigeration, Thermal Insulation and an Equipment for Healthy Ripening of Mango and Banana Without Using Harmful Chemicals", International Journal of Mechanical and Production Engineering Research and Development, (2019), vol. 09, no 1, pp.423-434.

10. Hasan, Haslinda, Amran Harun, and MohdShaffran Zainal Rashid. "Factors influencing online purchase intention in online brand." International Journal of Business Management \& Research 5.5 (2015): 63-72.

11. Ramesh Babu, D., Narasimha Rao, K. V., Satish Kumar, M. V. and Satish Kumar, B., "Handling of Apples During Sortinggrading Operation and Measuring the Mechanical Properties Firmness after Controlled Atmosphere Storage”, International Journal of Mechanical and Production Engineering Research and Development, (2018), vol. 8, no.6, pp. 617-634.

12. Ahi Pei, AudheshPaswan, Ruiliang Yan. E-tailer's return policy, consumer's perception of return policy fairness and purchase intention, Journal of Retailing and Consumer Services, (2014), 21 (3), 249-257.

13. Punekar, Sarika, and R. Gopal. "A Study to Identify Customer's Online Apparel Shopping Behavior in Relation to Return Policies of E-Commerce Businesses, WR To Pune Region, India." International Journal of Sales \& Marketing, Management Research and Development (IJSMMRD) 6.3 (2016): 1-6.

14. Thanh Tran, HareshGurnani, RamaraoDesiraju. Optimal Design of Return Policies, Marketing Science, (2018), 37 (4), $507-$ 684.

15. HannuSaarijärvi, Ulla-MaijaSutinen\& Lloyd C. Harris Uncovering consumers' returning behaviour: a study of fashion ecommerce, The International Review of Retail, Distribution and Consumer Research, (2017), (27) 3, 284-299.

16. Chen, J., Chen, B. and Li, W. Who Should Be Pricing Leader in the Presence of Customer Returns? European Journal of Operational Research, (2018), 265, 735-747.

17. Li, J. and Li, Y. Online Pricing and Compensation Optimizing Strategy un-der Unjustified Return Policy. System Engineering Theory and Practice, (2016), No. 11, 2811-2819.

18. Wang, Y., Anderson, J., Joo, S.-J., \&Huscroft, J. R. The leniency of return policy and consumers' repurchase intention in online retailing. Industrial Management and Data Systems, (2019), 120(1), 21-39.

19. D Ramesh Babu, SireeshaKoneru, K V Narasimha Rao, B Satish Kumar, SyamKolati, N Suman Kumar, "Identifying Opportunities to start Industries on the Food Production Potential in Telangana and Andhra Pradesh, India”, International Journal of Engineering and Advanced Technology, (2019), vol.8, no.5, pp.2189-2193.

20. Gupta, D. D., Babu, R. D. and Bawa, A. S. Effect of pre-fry drying on the quality of fried banana chips. Journal of Food 
Science and Technology-Mysore, (2006), 43(4), 353-356.

21. Agrawal, Kalpana, and HuzefaJaliwala. "Effect of social media on e-purchase amongst youth." International Journal of Business Management \& Research 3.2 (2013): 131-136.

22. Naredla, S. K., Shekar, P. R., Babu, D. R., and Condoor, S., "Uniquely Addressing Customer Pain Points-the Case Study of Agritech”, App. International Journal of Mechanical Engineering and Technology, (2018), vol.9, no.11, pp. 23062314.http://www.iaeme.com/IJMET/issues.asp? JType=IJMET\&VType=9\&IType $=11$.

23. E. Ramesh, D. Ramesh Babu and P. Ramchandar Rao, "The Impact of Project Management in Achieving Project SuccessEmpirical Study”, International Journal of Mechanical Engineering and Technology,(2018), vol.9, no.13, pp. 237247.http://www.iaeme.com/IJMET/issues.asp? JType=IJMET\&VType=9\&IType $=13$

24. P Sammaiah, D Ramesh Babu, L Radhakrishna, and P Rajendar, "Kinetics of Moisture Loss during Dehydration of Drum Stick Leaves (MoringaOliefera) In a Bio-Mass Tray Dryer", International Journal of Engineering and Advanced Technology,(2019), August, vol,8, no.6, pp.2937-2941.

25. Narasimha Rao K V, Shareef Shaik and Ramesh Babu. D, "Mathematical Modeling of Cooling Rates of Mango Fruits During Unsteady State Cooling in An Artificial Ripening Chamber", Test Engineering and Management, (2020), March-April, vol 83, pp.6862-6871.

26. Narasimha Rao K V, SasankDevarakonda and Ramesh Babu D, "Mathematical Modeling of Cooling Rates of Mango Fruits During Unsteady State Cooling in An Artificial Ripening Chamber”, Test Engineering and Management, (2020), March-April, vol 83, pp.6872-6879.

\section{AUTHORS PROFILE}

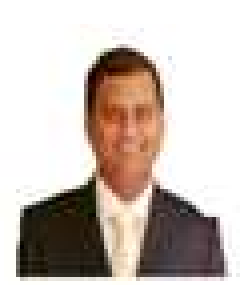

Dr Ram Deshmukh is Professor and Head of Electrical and Electronics Engineering Department. He has completed his under graduation at Nagpur University, $\mathrm{PhD}$ in the area of Energy Efficient Machines in 2007 from Cardiff University, United Kingdom. He has 12 years of Industrial Experience and 5 years of teaching experience in the UK. He was as Chief Engineer in ATB Laurence Scott, Senior Design Engineer in Brush Electrical Machines Ltd, Electrical Engineer in Corus Construction and Industrial Ltd (TATA Steel UK). He was lecturer in University of Sunderland. He is an international qualified teaching professional with PG Certificate in Higher Education from University of Sunderland. He have achieved many international awards that includes Dennis Hatfield memorial Prize for Best Article in UK Magnetic Society magazine,UKMAG, Business Contribution Award in Corus Steel UK, Excellent contribution as Design Mentor in Smart India Hackathon- Hardware Edition, Kharagpur, India. He received award from Steel Authority of India Ltd for Solving their Industry Problem during his undergraduate Studies. He also received Best presentation Award in Magnetism and Magnetic Conference, San Diego, USA. He have published technical research papers in reputed International Journals viz. IEEE Transactions of Magnetic Material, Journal of Applied Physics, Journal of Magnetism and Magnetic Material. He is the Director in a company named "Real Pandu", a fruit ripening company. 


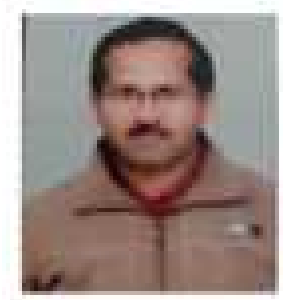

D. Ramesh Babu has got over 24 years of professional experience in manufacturing, research, maintenance, consultancy and project management of Refrigeration, Cold Storage and Controlled Atmosphere storage technologies.

He was graduated in Mechanical Engineering from JNTU College of Engineering, Hyderabad in the year 2000 and obtained MBA in production and operations management from MDU,Rohtak. He also obtained his MTech in Advanced Manufacturing from JNTU, Hyderabad. He has got expertise in refrigeration, fruit preservation and food processing. He is presently working as Assistant Professor in Mechanical Engineering at S R Engineering College, Warangal since year 2014. He has four years of experience in refrigeration equipment manufacturing at Voltas Limited, seven years of experience in fruit preservation at Defence food research laboratory, DRDO-Mysore and worked for eight years at cold chain project of CONCOR before joining teaching.

He is a recipient of DRDO cash award in the year 2003. He was nominated by CONCOR for eight days visit to ISRAEL as part of cold chain project for preservation of apples in the year 2011. He has published 4 research papers in SCI indexed journal, 15 papers in SCOPUS indexed journals and 6 in ICI indexed journals. He also presented numerous papers at various International and national conferences. His paper got best paper award by the TJPRC for the paper on “The Design of Refrigeration, Thermal Insulation and an Equipment for Healthy Ripening of Mango and Banana without Using Harmful Chemicals.” published in IJMPERD.

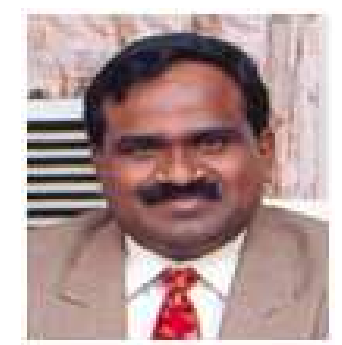

Dr K V Narasimha Rao is a senior Professor with 27+ years experience in Academic, Consultancy and Industry and has been working with KLEF (Deemed to be University) Vaddeswaram since 2 September 2016. DrNarasimha Rao was graduated in Mechanical Engineering from Regional Engineering College, Warangal in 1986 and went on to obtain Master's and Doctoral degrees from the Indian Institute of Science, Bangalore during 1990 and 1995 respectively in the field of Thermal Engineering. He worked for seven years (1995-2002) as Research Associate and Fellow, Industrial Energy Group at Tata Energy Research Institute (teri), Southern Regional Centre, Bangalore before moving into Academics in 2002. Prior to joining KLEF, he worked at few Engineering Colleges as Principal/Director/Dean.Dr Rao has published 40 scientific papers (three in SCI Listed Journals, 30 Scopus indexed Journals and Chapter 10 in Recent Advances in Material Sciences, Lecture Notes on Multidisciplinary Industrial Engineering) and numerous technical reports for various National/International Agencies. HE has filed 14 patents (three published).

Membership of Professional Bodies: 
Dr Rao is a member of ASHRAE, ISCA, ISHMT, ISHRAE, ISTE \& SESI and Fellow of Institution of Engineers (India).

Scholarships \& Awards:

- $\quad$ Recipient of 'National Merit Scholarship' during 1980-85 (6 Years).

- Recipient of 'Special Rank' in Mathematics Olympiad conducted by Andhra Pradesh Association of Mathematics Teachers (APAMT), Hyderabad, A. P. at Senior Level during 1980-81.

Areas of Specialization:

- Energy Auditing, Energy Conservation \& Management, Heat Transfer, Refrigeration \& Air-conditioning and Renewable Energy Sources.

Research Guidance:

Supervised 14 M. Tech. Students and presently guiding Six PhD Scholars and four M. Tech. Students.

Important Projects handled:

- Dr Rao was the Team Leader for the Consultancy Assignment on Energy Efficiency Services-Phase-III (3 May30 November 1998), for the Ministry of Industry, His Majesty's Govt. of Nepal, Industrial Energy Management Component of the Power Sector Efficiency Project (PSEP) - IDA Credit No. 2347-NEP, World Bank. The activities included Demand Side Management (DSM), Furnace \& Kiln and Boiler Efficiency studies, Cogeneration Feasibility studies covering 65 major industries in Nepal. Trained 11 Nepalese Engineers as Certified Energy Auditors as part of the Consultancy Assignment.

- Dr Rao was involved in the field-testing of a number of Energy Saving Devices / Retrofits under the Energy Saving Demonstration Project, funded by GTZ, Germany.

- Dr Rao has developed and Demonstrated "Performance Contract for Industrial Energy Management" for Indian Scenario, sponsored by Canadian International Development Agency.

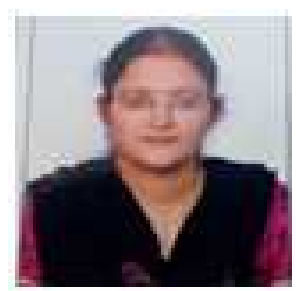

D RaghavaKumari is currently working as Assistant Professor in Department of Electronics and Communications Engineering at SumathiReddy Institute of Technology for Women, Warangal, and Telangana. She has got 10+ years of experience in teaching and research. She has published two research papers in Scopus indexed journals. Her research interests are electronic systems, Communication systems and mathematical modeling. 